\title{
MATHEMATICAL MODELING OF TECHNOLOGICAL PROCESS OF ROASTING VEGETABLES IN OIL
}

\author{
A. Tokar, S. Muronyuk, T. Volkova \\ Uman National University of Horticulture
}

\begin{tabular}{l}
$\quad$ Key words: \\
Roasting \\
Oil absorption \\
Moisture removal \\
Optimal regime \\
Heat-mass transfer \\
\hline
\end{tabular}

Article history:

Received 15.01.2018

Received in revised form 02.02 .2018

Accepted 16.02.2018

Corresponding author:
A.Tokar
E-mail:
topvolkova@gmail.com

\begin{abstract}
The process of roasting is obligatory in the technology of production of vegetable canned snacks, as a result of which the product acquires a peculiar taste and smell, and due to the removal of moisture and oil uptake, its nutritional value rises. Roasted vegetables have soft, elastic consistency and are better absorbed by the body.

The process of roasting vegetables is a complex set of phy-
\end{abstract} sical, chemical, physical-chemical and technological processes, complicated by heat-mass-exchange and by ability to absorb oil.

In the thermal stage of congealment, no visible disturbances in the cell structure are observed, except for the coagulation of the protoplasmic substance. This stage is the initial phase of the transformation of plant tissue during frying and occurs at moderate temperatures.

The swelling phase coincides with the onset of evaporation, as a result of which the volume of cells increases; their size becomes much larger than before heating, so they appear swollen under a microscope. Coagulant matter is condensed. At this stage, technological readiness has not yet been reached, because the vaporization has just begun, but the vapor has not yet left the tissue.

The next stage is an internal evaporation, in which a significant part of moisture in the form of vapor leaves the cell, which makes the cell decrease in size, shrink. The shape of the cells becomes very disturbed. The loss of the cellular structure of the tissue begins, air voids become appeared. Practice has established that the optimal percentage of smelting, and the required moisture content is reached at this stage, and the raw material should be taken out of the oven.

With the traditional method of frying eggplants, a significant amount of oil is absorbed (more than 12\%), which limits their consumption due to high caloric content. One of the effective ways to reduce the amount of oil in roasted vegetables is to pre-soak them or blanch in water: moisture will prevent the absorption of oil. The process of oil absorption, and hence the quality of the finished product, depends on a large extent of the physical and chemical properties of the fruit associated with the storage conditions of the raw materials.

In order to reduce the absorption of the oil, the process of roasting is optimized due to preliminary soaking or blanching of eggplants in water, and the mathematical model of the process is developed according to traditional and advanced technologies.

DOI: $10.24263 / 2225-2924-2018-24-1-29$ 


\title{
МАТЕМАТИЧНЕ МОДЕЛЮВАННЯ ТЕХНОЛОГІЧНОГО ПРОЦЕСУ ОБСМАЖУВАННЯ ОВОЧІВ В ОЛІЇ
}

\author{
А.Ю. Токар, С.С. Миронюк, Т.В. Волкова \\ Уманський національний університет садівництва
}

Прочес обсмажування є обов'язковим в технології виробничтва овочевих закусочних консервів, в результаті якого продукт набуває своєрідного смаку $i$ запаху, а за рахунок видалення частини вологи та вбирання олії підвищується його харчова чінність. Обсмажені овочі мають м'яку, пружну консистениію і краще засвоюються організмом.

Прочес обсмажування овочів - ие складний комплекс фізичних, хімічних, фізико-хімічних і технологічних процесів, ускладнений тепломасообміном $i$ вбиранням олії. Зміни, щэо проходять у рослинній клітині при обсмажуванні, поділяються на такі послідовні стадіі: теплового заклякання, набухання, внутрішнього випаровування, деформачії і деструкиї, хімічного руйнування.

У стадії теплового заклякання видимих порушень у клітинній структурі не спостерігається, за винятком коагуляиії протоплазматичної речовини. Ця стадія є початковою фазою перетворень рослинної тканини при обсмажуванні і відбувається за помірних температур.

Стадія набухання збігається з початком пароутворення, внаслідок чого об'єм клітин збільшується, розмір їх стає значно більщим, ніж до нагрівання, тому під мікроскопом вони здаються набухлими. Коагульована речовина ущільнюється. У иій стадії технологічна готовність іще не досягнута, тому що пароутворення тільки розпочалося, але пара ще не вийшла за межі тканини.

Далі наступає стадія внутрішнього випаровування, при якій значна частина вологи у вигляді пари виходить з клітини, яка при изому зменшується в розмірах, стискується. Форма клітин порушується. Розпочинається втрата клітинної будови тканини, з'являються повітряні порожнечі. Практикою встановлено, що саме в иій стадії досягається оптимальний процент усмажування, необхідний вологовміст, і сировину слід забирати з печі.

За традииійного способу обсмажування баклажанів відбувається вбирання значної кількості олії (понад 12\%), що обмежує їх спожсивання через високу калорійність. Одним із ефективних способів зменшення вмісту олії в обсмажених овочах $\epsilon$ їх попередне замочування або бланшування у воді: волога перешкоджатиме всмоктуванню олії. Процес вбирання олії, а отже, $i$ якість готової продукиї значною мірою залежить від фізико-хімічних властивостей плодів, пов язаних з умовами зберігання сировини.

3 метою зниження вбирання олії оптимізовано процес обсмажування завдяки попередньому замочуванню чи бланшуванню баклажанів у воді і розроблено математичну модель процесу за традиџийною та за удосконаленою технологіями.

Ключові слова: обсмажування, вбирання олії, видалення вологи, оптимальний режим, тепломасообмін. 
Постановка проблеми. За традиційного способу обсмажування баклажанів відбувається вбирання значної кількості олії (понад 12\%), що обмежує їх споживання через високу калорійність. Одним з ефективних способів зменшення вмісту олії в обсмажених овочах $\epsilon$ їх попереднє замочування або бланшування у воді: волога перешкоджатиме вбиранню олії.

Аналіз останніх досліджень і публікацій. Дослідженням процесів обсмажування рослинної сировини зокрема з питань випарювання вологи і гістологічних змін рослинної тканини в процесі обсмажування, займалися К.А. Бауер, М.І. Смирнов, В.М. Расходова. Пізніше важливі дослідження, що забезпечують удосконалення техніки і технології обсмажування продуктів, були виконані Т.Л. Роматовською, А.М. Мальським, С.В. Шияном.

Мета дослідження: створення математичної моделі технологічного процесу обсмажування баклажанів в олії.

Матеріали і методи дослідження. Плоди баклажана сорту Алмаз були зібрані в технічній стадії стиглості, якість яких відповідала вимогам ДСТУ 2660 «Баклажани свіжі. Технічні умови».

Викладення основних результатів дослідження. Визначення оптимальних режимів попереднього оброблення плодів баклажана, нарізаних кружками товщиною 20 мм, замочуванням і бланшуванням у воді проводили за температури води $20 \ldots 100^{\circ} \mathrm{C}$ тривалістю $1 \ldots 30$ хв. За контроль приймали кружки баклажанів без оброблення. Нарізані на кружки баклажани перед обсмажуванням замочували або бланшували у воді за різних температур та визначали кількість увібраної вологи.

У процесі замочування спостерігалась тенденція: кружки баклажанів повільно і поступово вбирали воду, з підвищенням температури процес відбувався більш інтенсивно.

Найбільше поглинання вологи кружками баклажанів відбувалося в процесі замочування у варіанті з режимом $20^{\circ} \mathrm{C}$, тривалістю 20 хв. При подальшому збільшенні тривалості замочування кружків збільшення поглинання вологи не спостерігалось. У процесі бланшування максимальна кількість увібраної вологи спостерігалась у варіанті з режимом $80^{\circ} \mathrm{C}$ тривалістю 3 хв. За температурних режимів вище $80^{\circ} \mathrm{C}$ тривалістю більше 5 хв спостерігалося порушення тургору клітин плодів, консистенція ставала м'якою, кружки баклажанів втрачали форму і були непридатними для подальших досліджень.

Оптимальними були визнані зразки баклажанів за режимів оброблення: замочування - температура $20^{\circ} \mathrm{C}$, тривалість 20 хв; бланшування - температура $80^{\circ} \mathrm{C}$, тривалість 3 хв, у яких спостерігалось збільшення вологовмісту на $8,2 \%$ порівняно $з$ контролем (без оброблення).

Подальші дослідження процесу обсмажування проводились з баклажанами, нарізаними на кружки, вказаних варіантів попереднього оброблення.

При дослідженні процесу обсмажування за контроль були прийняті плоди баклажана, нарізані кружками, без попереднього оброблення. Дослідними зразками були плоди баклажана, нарізані кружками товщиною 20 мм, попередньо замочені у воді за температури $20^{\circ} \mathrm{C}$ тривалістю 20 хв, і кружки баклажанів, попередньо бланшовані у воді за температури $80^{\circ} \mathrm{C}$ тривалістю 3 хв. Обсмажування баклажанів проводили в обсмажувальних печах 3 електро- 
нагріванням за температур: $130^{\circ} \mathrm{C}, 135,140,145,150^{\circ} \mathrm{C}$, тривалістю до 7 хв iз визначенням досліджуваних показників через кожну хвилину. Процес обсмажування вважався закінченим при досягненні зразками показника видимого відсотка усмажування понад 20\% 3 утворенням кірочки світло-золотистого кольору. Масову частку жиру в обсмажених баклажанах визначали екстракційно-ваговим методом.

Схема досліду з удосконалення процесу обсмажування з метою зменшення вбирання олії баклажанами наведена на рис. 1. Дослід трифакторний, виконаний у трьох повтореннях: фактор А - попереднє оброблення; фактор В - тривалість обсмажування; фактор С - температура олії.

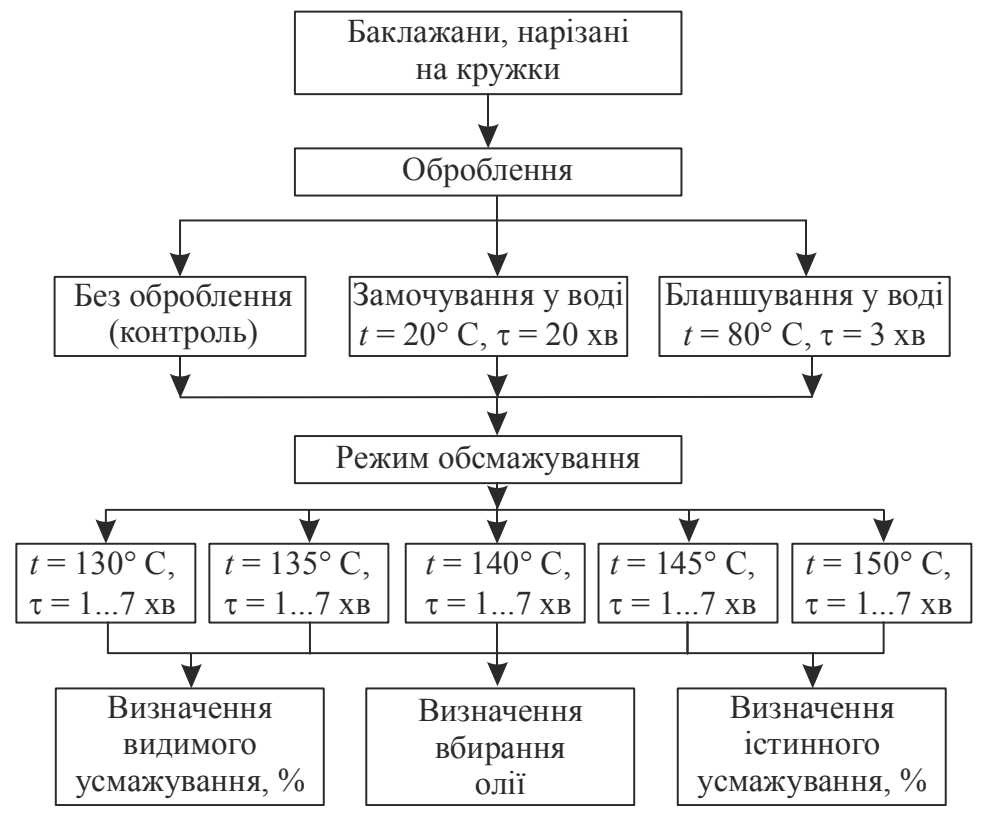

Рис. 1. Схема досліду з удосконалення процесу обсмажування зетою зменшення вбирання олії баклажанами

Унаслідок обсмажування овочі набувають приємного смаку і запаху, зовнішнього вигляду, збільшується їх калорійність - частково у результаті випаровування з овочів вологи, а в основному — завдяки вбиранню олії [1-5]. Тому були сплановані і проведені дослідження з визначення вбирання олії за різних температур $\left(130^{\circ} \mathrm{C}, 135,140,145,150^{\circ} \mathrm{C}\right)$ попередньо замоченими $\mathrm{i}$ бланшованими баклажанами, нарізаними на кружки. Результати досліджень за температури обсмажування $140^{\circ} \mathrm{C}$ наведені на рис. 2 .

$$
\mathrm{HIP}_{05}=0,46
$$

За результатами досліджень (рис. 2), кількість увібраної олії баклажанами контрольного зразка протягом усього періоду обсмажування відзначалося вищими значеннями, порівняно 3 варіантами, що піддавались обробленню. Починаючи з третьої хвилини і до закінчення процесу спостерігалися істотні різниці: між контролем і першим варіантом - 1,6\%, між контролем і другим варіантом - $2,1 \%$, що вказує на доцільність попереднього оброблення бакла- 
жанів при обсмажуванні. Винятком була перша хвилина обсмажування, коли показники вбирання олії у контролі і першому варіанті були однаковими, а варіант 2 переважав контроль на 0,3\%, що неістотно. Це можна пояснити коротким періодом теплового оброблення баклажанів, за якого процес взаємодії сировини і олії при обсмажуванні ще не врівноважилися.

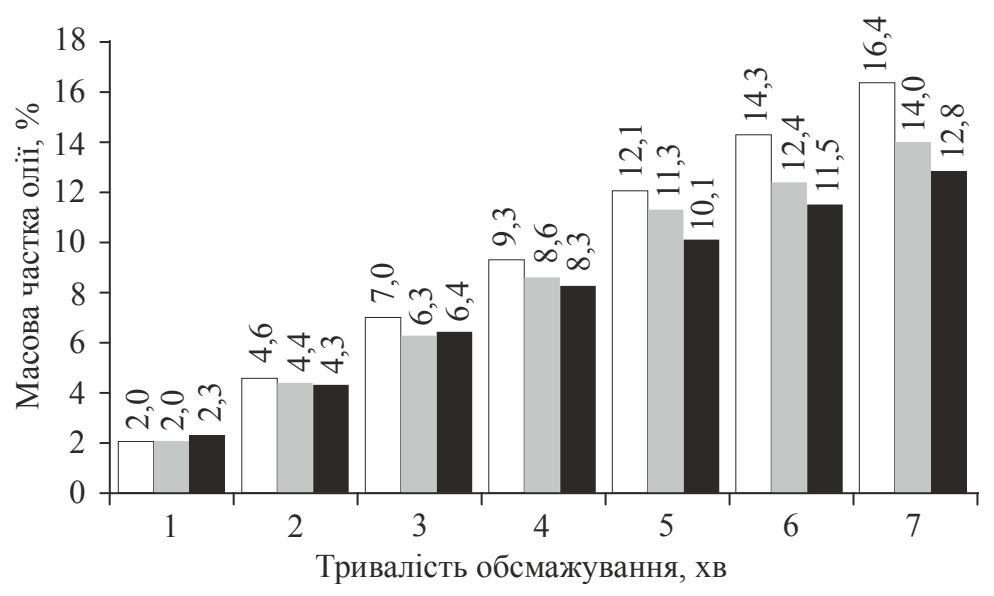

Рис. 2. Вбирання олії баклажанами, нарізаними на кружки, за температури $140^{\circ} \mathrm{C}$ залежно від попереднього оброблення (фактор А) і тривалості обсмажування

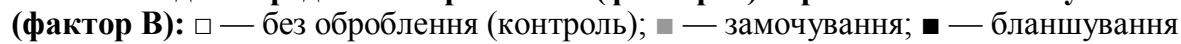

Оптимальний температурний режим обсмажування баклажанів становив $140^{\circ} \mathrm{C}$ тривалістю 7 хв за органолептичними показниками.

Для дослідження впливу основних факторів на вбирання олії за обсмажування баклажанів необхідно розробити математичну модель процесу з використанням результатів, отриманих під час реалізації повного факторного експерименту. Детермінована залежність нам невідома, оскільки невідомі зв'язки між вхідними і вихідними параметрами, тобто ми маємо модель у вигляді «чорного ящика» [6].

Унаслідок попередньо отриманих результатів визначені такі вхідні параметри, які найбільше впливають на процес обсмажування баклажанів:

$\tau$ - тривалість процесу, хв;

$t$ - температура процесу, ${ }^{\circ} \mathrm{C}$.

Вихідна функція (критерій оптимальності в обсмажених баклажанах):

$\hat{C}_{\text {оліi }}$ - вміст олії.

У загальному вигляді функцію можна представити так:

$$
C_{\text {oiii }}=f(\tau, t)
$$

Загальна схема математичної моделі має вигляд:

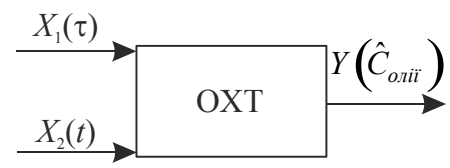

Рис. 3. Загальна схема математико-статистичної моделі 
Для проведення дослідів складений план експерименту із зазначенням кількості дослідів і меж зміни факторів.

Матриця являє собою перелік варіантів, взятих у даній серії дослідів. Відомо, що найбільш простими $є$ матриці повного факторного експерименту (ПФЕ), в яких досліджувані фактори змінюються лише на двох рівнях: верхньому та нижньому.

Визначивши, які фактори впливають на вміст олії в обсмажених баклажанах, визначаємо їх рівні та крок варіювання, які наведені у табл. 1.

Таблиия 1. Рівні і кроки варіювання факторів

\begin{tabular}{|c|c|c|c|c|c|}
\hline Фактор & $\begin{array}{c}\text { Одиниці } \\
\text { вимірювання }\end{array}$ & 0-рівень & $\begin{array}{c}\text { Крок } \\
\text { варіювання }\end{array}$ & $\begin{array}{c}\text { Верхній } \\
\text { рівень «+» }\end{array}$ & $\begin{array}{c}\text { Нижній } \\
\text { рівень «-» }\end{array}$ \\
\hline$x_{1}(\tau)$ & Хв & 4 & 3 & 7 & 1 \\
\hline$x_{2}(t)$ & ${ }^{\circ} \mathrm{C}$ & 140 & 10 & 150 & 130 \\
\hline
\end{tabular}

Наступним кроком $є$ побудова матриці повного двофакторного експерименту, яка наведена в табл. 2 .

Таблиця 2. Матриця повного двофакторного експерименту

\begin{tabular}{|c|c|c|c|c|c|c|c|c|}
\hline № досл. & $z_{0}$ & $z_{1}$ & $z_{2}$ & $z_{1} z_{2}$ & $y_{1}$ & $y_{2}$ & $\bar{y}$ & $S_{i}^{2}$ \\
\hline 1 & + & + & + & + & 19,2 & 18,8 & 19 & 0,08 \\
\hline 2 & + & + & - & - & 16 & 16,4 & 16,2 & 0,08 \\
\hline 3 & + & - & + & - & 2,5 & 2,3 & 2,4 & 0,02 \\
\hline 4 & + & - & - & + & 2 & 2 & 2 & 0 \\
\hline
\end{tabular}

Тоді математична модель буде мати вигляд:

$$
\hat{C}_{\text {олї }}=0,02 \tau t-0,233 \cdot \tau-0,367 .
$$

3 метою наглядного зображення результатів досліджень було побудовано поверхню відгуку системи (рис. 4).

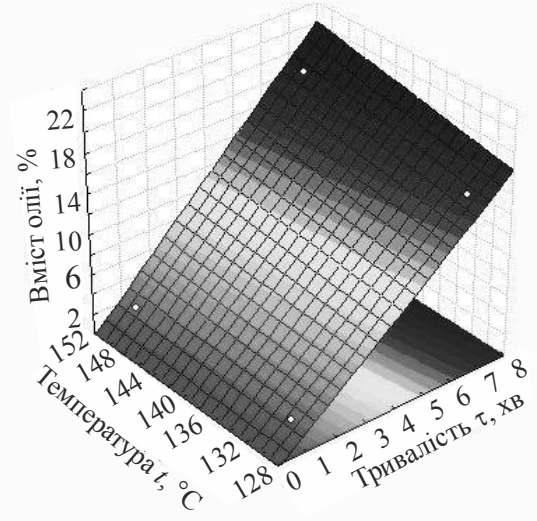

Рис. 4. Поверхня відгуку математичної моделі вбирання олії залежно від тривалості і температури процесу 
За допомогою графічної моделі процесу за двома відомими параметрами можна визначити третій, якій лежить на відповідній площині.

\section{Висновок}

Розроблену математичну модель процесу перевірено на адекватність, що дає можливість розрахувати кількість олії, увібраної баклажанами, нарізаними на кружки, залежно від температури олії й тривалості процесу.

\section{Література}

1. Мальский А.Н. Процесс обжаривания овощей и автоматизация обжарочных печей / А.Н. Мальский — Москва : Пищевая промышленность, 1976. — 160 с.

2. Мальский А.Н. Овощные закусочные консервы / А.Н. Мальский, А.К. Изотов. Москва : Пищевая промышленность, 1978. - 229 с.

3. Технологічна інструкція по виробництву консервів «Закусочні страви» (Згідно ТУ У 15.3-05305810-002:2006), затв. 24.07. 2006. - 24 с.

4. Консерви. Закусочні страви. Технічні умови: ТУ У $15.3-05305810-002: 2006$. Уперше. [Чинні від 2006-12-01]. Київ :Держстандарт України, 2006. — 19 с.

5. Гореньков Э.С. Научное обеспечение производства плодоовощной продукции / Э.С. Гореньков // Пищевая промышленность, 2002. —№ 2. — С. 54-56.

6. Кафаров В.В. Математическое моделирование основных процессов химических производств / В.В. Кафаров, М. Б. Глебов. — Москва : Высшая школа, 1991. — 457 с. 